\title{
Investigations of Catalytic Methane Oxidation under Lean Wet Exhaust Conditions
}

\author{
Sirichai Jirawongnuson $^{1)}$ Tul Suthiprasert ${ }^{1)} \quad$ Tanet Aroonsrisopon $^{1)}$
}

\author{
Ekathai Wirojsakunchai $^{1)}$ Krisada Wannatong ${ }^{2)} \quad$ Atsawin Salee $^{2)}$
}

\author{
1) Department of Mechanical Engineering, Faculty of Engineering, Kasetsart University, Bangkok, Thailand \\ (E-mail:fengeka@ku.ac.th) \\ 2) PTT Public Company Limited, Bangkok, Thailand
}

Received on June $17^{\text {th }}, 2019$

\begin{abstract}
This current research work has been focused on Methane $\left(\mathrm{CH}_{4}\right)$ reduction in a Diesel Oxidation Catalyst (DOC) emitted from a Dual Fuel-Premixed Charged Compression Ignition (DF-PCCI) engine. This new alternative combustion technology is implemented on a Diesel Engine powered by both diesel fuel and natural gas in order to reduce diesel fuel usage and maintain the same thermal efficiency. However, the drawback lies in higher amount of $\mathrm{CH}_{4}$ in the exhaust that might effects Original Equipment Manufacturer (OEM)'s DOC performance. In this work, thermophysical and chemical properties of DF-PCCI exhaust such as temperature, flow rate, and specie concentrations are varied to investigate their effects on $\mathrm{CH}_{4}$ conversion efficiency in DOC. Design of Experiment (DOE) is built and tested in a Synthetic Exhaust Gas Generating System that can simulate the DF-PCCI exhaust-like conditions and all tested parameters are fully controlled. The experimental matrix is selected to cover DF-PCCI exhaust condition ranges to optimizing $\mathrm{CH}_{4}$ treatment. A kinetic model with water concentration is also investigated and compared to DOE model and experimental data. It is shown that the major factors that influence methane oxidation are exhaust flow rate, $\mathrm{H}_{2} \mathrm{O}$ concentration, and exhaust temperature (at $\mathrm{P}$-value $<0.05$ or at confidence level of $95 \%$ ). The DOE model for predicting $\mathrm{CH}_{4}$ reductions is also generated.
\end{abstract}

KEY WORDS: Methane Oxidation, Diesel Oxidation Catalyst, DF-PCCI Combustion (A1)

\section{Introduction}

Developments of Diesel Dual Fuel (DDF) Engines in Thailand are done aggressively in the past few years because of the awareness of high diesel fuel price and renewable energy usages. PTT Research \& Technology Institute has studied and adapted Diesel Dual Fuel Concept using Natural Gas ${ }^{(1)}$. Natural Gas mainly composed of $\mathrm{CH}_{4}$ is suitable for being a primary fuel because of its low price and ready-to-use in Thailand's fuel distribution infrastructure ${ }^{(2)}$. DDF engines is more advantage than a dedicated engine (uses natural gas as their only fuel source) because of its high thermal efficiency and low soot/NOx emissions (3). However, unburned hydrocarbons, especially $\mathrm{CH}_{4}$, and $\mathrm{CO}$ from incomplete combustion are high relative to emissions from diesel combustion ${ }^{(4-7)}$. PTT Research \& Technology Institute has also introduced the new DDF combustion concept for light-duty diesel engine applications called Dual Fuel-Premixed Charge Compression Ignition (DF-PCCI), in which injection timing, amount of EGR usages, and throttle angle position are fully controlled by Engine Control Unit (ECU) corresponding to various engine speeds and load requirements while the ratio of $\mathrm{CH}_{4}$ to diesel fuel amount usages is under 70:30.

With more health and pollution concerns, many experimental and simulation researches on DF-PCCI combustion are conducted including improvement of diesel fuel injection strategy both in quality and quantity, intake temperature, and coolant temperature but they still fell short on reducing in-cylinder methane emissions in order to pass stringent emission standards ${ }^{(8-11)}$. For an aftertreatment point of view, $\mathrm{CH}_{4}$ is one of the most stable species that is hard to catalytically oxidize at low exhaust temperatures under lean burn environment (high $\mathrm{O}_{2}$ concentration in the exhaust). A temperature range between 400 and $500^{\circ} \mathrm{C}$, which is much higher than those in front of DOC, is required. A typical catalytic converter is far from being a perfect solution for DF-PCCI emission problems. Literatures from ${ }^{(12-15)}$ has pointed out that thermal and chemical properties of the exhaust such as flow rate, specie concentrations, and temperature are significant to $\mathrm{CH}_{4}$ reductions in DOC. It is shown that high exhaust flow rate and high $\mathrm{CH}_{4}$ concentrations reduce DOC performance. However, if $\mathrm{O}_{2}$ concentrations and exhaust temperature are increased, $\mathrm{CH}_{4}$ conversion efficiency can be increased. In addition, $\mathrm{H}_{2} \mathrm{O}$ concentration in the exhaust has been known as one of the inhibitors for $\mathrm{CH}_{4}$ oxidation in DOC. $\mathrm{CH}_{4}$ oxidation of $\mathrm{Pd}$ coupled to various types of washcoats on different water concentrations has been widely studied ${ }^{(16-19)}$. Results show that higher percentages of water concentrations in the exhaust require higher $\mathrm{CH}_{4}$ light-off temperature at $30 \%$ conversion efficiency. Lapisardi et al. demonstrate the experiments for $\mathrm{CH}_{4}$ oxidation with and without water in real-time tests. At the beginning, water is injected into the feed and then is stopped at the time of $8 \mathrm{hr}$. As seen from the result, without water injection, $\mathrm{CH}_{4}$ conversion efficiency increases from $10 \%$ to $70 \%$ at the same temperature. Based on past literatures, they 
have shown that both thermal (flow rate, temperature) and chemical properties (specie concentrations) of the exhaust influence $\mathrm{CH}_{4}$ oxidation rate. However, relationships among these parameters should have been also paid attention to. Past research studies are not covered in this topic area yet. Thus, the main objective of this work is to employ the DOE concept to identify most impact parameters and their relationships to gain more fundamental understandings of $\mathrm{CH}_{4}$ oxidation in DOC by performing both experiments and simulations. Once the knowledge is established, optimizing $\mathrm{CH}_{4}$ conversion efficiency can be done to better DOC performance

\section{Experiment Setup and Matrix}

Among past literatures, of all thermal and chemical exhaust properties, it has been identified that there are five parameters: exhaust flow rate, exhaust temperature, $\mathrm{HC}$ concentration, $\mathrm{O}_{2}$ concentration, and $\mathrm{H}_{2} \mathrm{O}$ concentration influence $\mathrm{CH}_{4}$ conversion efficiency in DOC. These five parameters are fully controlled by using Synthetic Exhaust Gas Generator to mimic exhaust-like conditions found from the real diesel engine that is adapted to DFPCCI combustion operation. The Synthetic Exhaust Gas Generating System can mix CO, $\mathrm{CO}_{2}, \mathrm{C}_{3} \mathrm{H}_{8}, \mathrm{CH}_{4}, \mathrm{NO}, \mathrm{N}_{2}$, and $\mathrm{H}_{2} \mathrm{O}$ into purified dry air at desired concentrations using Mass Flow Controllers (Part 1 in Fig. 1), while controls the temperature using a series of electrical heaters (Part 2 in Fig. 1), and monitor each specie concentrations before and after DOC by FTIR Exhaust Emission Analyzer manufactured by AVL, Inc. Model AMA i60 (Part 3 in Fig. 1) to obtain catalyst conversion efficiency. DOC is placed in an electric oven in order to control DOC surface temperature. This setup can be also adapted to perform Temperature Programmed Oxidation (TPO) experiments to obtain light-off temperature of each gas species. More details of this setup can be found in ${ }^{(20)}$.

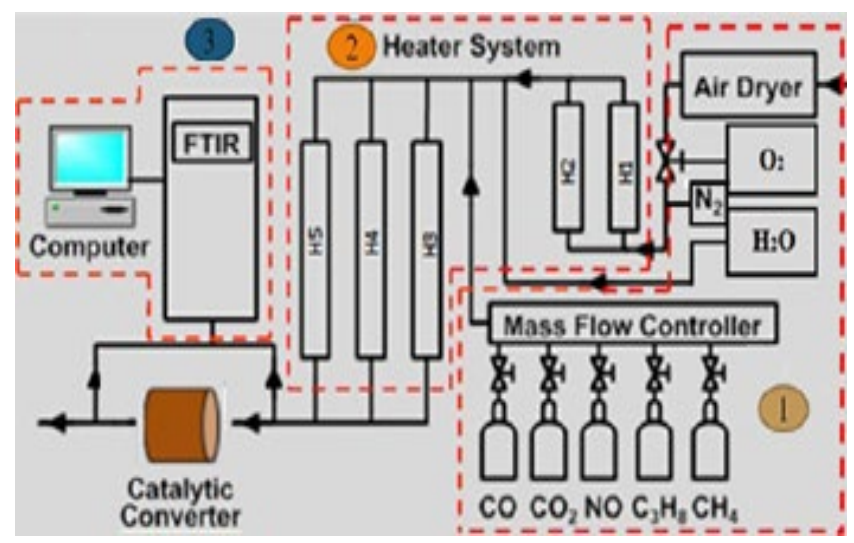

Fig. 1. Synthetic Exhaust Gas Generating System

The properties of the DOC used in the current study can be found in Table 1. Note that this DOC is manufactured by ECOCAT and specifically designed to meet EURO IV emission standard for a natural gas vehicle. The substrate is made of aluminum foil and is implemented new washcoat techniques to enhance the active site of the catalyst. More details can be found in ${ }^{(21)}$.
Table 1. Tested DOC Properties

\begin{tabular}{|l|c|}
\hline \multicolumn{1}{|c|}{ Parameter } & Tested DOC \\
\hline Cell Per Square Inch $(\mathrm{CPSI})$ & 400 \\
\hline Cell Shape & Triangular \\
\hline Volume $(\mathrm{L})$ & 2.0 \\
\hline PGM Loading $\left(\mathrm{gm} / \mathrm{m}^{3}\right)$ & 8,834 \\
\hline Pt $:$ Pd & $1: 4$ \\
\hline
\end{tabular}

\subsection{Emissions from Tested Vehicle}

A Turbocharged, Common rail, Direct Injection Diesel Engine of 2.5 Liter has been adapted to run with DF-PCCI combustion concept as mentioned earlier. The engine is tested under New European Driving Cycle (NEDC) standard on an Engine Dynamometer in the test room. Concentrations of each gas species, exhaust temperature, and flow rate are measured. Fig. 2 shows a comparison of $\mathrm{CH}_{4}$ emissions from Diesel to those from DF-PCCI combustion during NEDC test. As seen from many past literatures $(1,8,9,20), \mathrm{CH}_{4}$ emissions from DF-PCCI combustion is relatively high and since exhaust temperature (Fig. 3 ) is low, there is no $\mathrm{CH}_{4}$ conversion in DOC. The levels of $\mathrm{CH}_{4}$ emissions from Pre-DOC and Post-DOC are almost identical. Note that, $\mathrm{CH}_{4}$ emissions from DF-PCCI are started to emit after 180 seconds since the test begins. This is because the tested engine is started running from Diesel mode and then switched to DF-PCCI once the coolant temperature is on the set point which is approximately after 180 seconds.

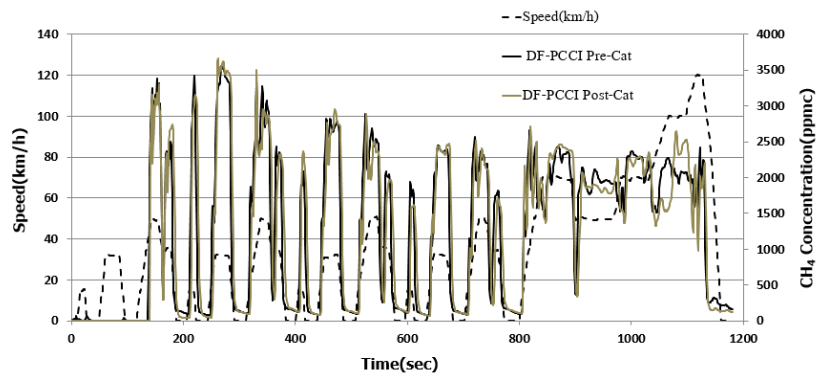

Fig. 2. A Comparison of $\mathrm{CH}_{4}$ Emissions between Diesel and DF-PCCI combustion during NEDC test

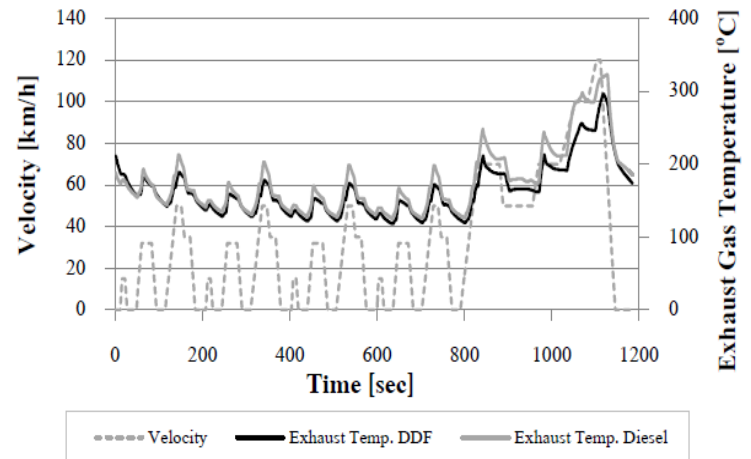

Fig. 3. A Comparison of Exhaust Temperature between Diesel and DF-PCCI combustion during NEDC Hot Test

From Fig. 2, it can be clearly seen that high $\mathrm{CH}_{4}$ emissions occur during Urban Driving Cycle (UDC) test. Fig. 4 shows percentages of $\mathrm{CH}_{4}$ emissions under idle, acceleration, steady, and break in one UDC loop. The highest amounts of $\mathrm{CH}_{4}$ emissions is under steady part. 


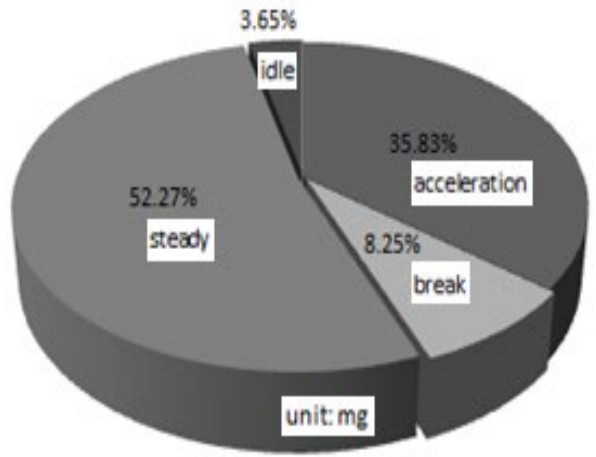

Fig. 4. Percentages of $\mathrm{CH}_{4}$ Emissions under an Urban Driving Cycle Test (Combining Each Part during $1^{\text {st }}, 2^{\text {nd }}, 3^{\text {rd }}$ Loop)

\subsection{Design of Experiment (DOE)}

DOE are designed based on experimental data obtained from Fig. 2-4. Since the ultimate goal of the current study is to optimize $\mathrm{CH}_{4}$ reductions in DOC, experimental data during steady tests are chosen to become low-high level parameters of DOE. Table 2 lists important thermal and chemical exhaust properties and their lowhigh levels based on the experimental data. Note that some of parameters are constant because the averaged value of low-high levels are almost the same. Also the temperature is set to be between 250 and $350^{\circ} \mathrm{C}$ which is higher than real exhaust temperature as shown in Fig. 3. This is due to the operating temperature window of the tested DOC that is shown in ${ }^{(20)}$ and ${ }^{(22)}$.

Table 2. Exhaust Properties and Their Low-High Levels during Steady Tests

\begin{tabular}{|l|l|}
\hline \multicolumn{1}{|c|}{ Item } & Low - High Level \\
\hline $\mathrm{CH}_{4}$ Concentrations (ppm) & $1,000-3,000$ \\
\hline $\mathrm{H}_{2} \mathrm{O}$ Concentrations (\%) & $0-4$ \\
\hline $\mathrm{O}_{2}$ Concentrations (\%) & $14-18$ \\
\hline $\mathrm{CO}_{2}$ Concentrations (ppm) & 30,000 \\
\hline $\mathrm{CO}_{2}$ Concentrations (ppm) & $500-7,000$ \\
\hline $\mathrm{C}_{3} \mathrm{H}_{8}$ Concentrations (ppm) & 1,000 \\
\hline $\mathrm{NO}_{x}$ Concentrations (ppm) & 30 \\
\hline $\mathrm{N}_{2}$ Concentrations & Balanced \\
\hline Flow Rate $(\mathrm{kg} / \mathrm{hr})$ & $20-60$ \\
\hline Space Velocity $(1 / \mathrm{hr})$ & $17,000-53,000$ \\
\hline Temperature $\left({ }^{\circ} \mathrm{C}\right)$ & $250-350$ \\
\hline
\end{tabular}

Box-Behnken design is chosen for the current study. The software package, namely Minitab, is used for designing experimental matrix as shown in Table 3. Five factors: $\mathrm{CH}_{4}$ concentrations, $\mathrm{O}_{2}$ concentrations, flow rate, $\mathrm{H}_{2} \mathrm{O}$ concentrations, and temperature are main factors in DOE. The low-high levels for each factors are based on experimental data shown in Table 2.

\subsection{Simulation Setup}

The simulation in this study is employed by using a commercial software package, namely AVL Boost, which is a 1D simulation program that is designed to analyze engine related problems coupled with aftertreatments. This research collaboration with AVL has been done via AVL AST UNIVERSITY PARTNERSHIP PROGRAM. The software package provides a user defined function that allows users to implement their own kinetic models into the program. Fig. 5 demonstrates a flow chart of oxidation mechanisms in a DOC model as seen in AVL Boost manual.

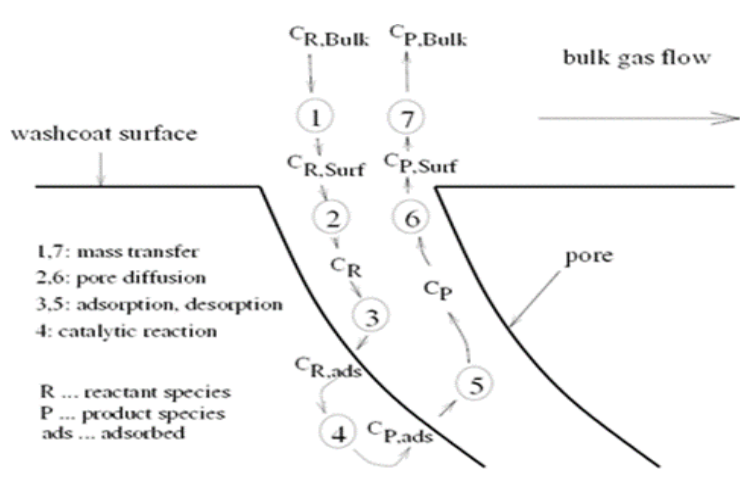

Fig. 5. Flow chart of the after treatment analysis.

Table 3. DOE for Five Chosen Parameters According to BoxBehnken Design (units of each parameters are the same as listed in Table 2)

\begin{tabular}{|c|c|c|c|c|c|c|c|c|c|c|c|}
\hline No & $\mathrm{CH}_{4}$ & $\mathrm{O}_{2}$ & Flow rate & $\mathrm{H}_{2} \mathrm{O}$ & Temp & No & $\mathrm{CH}_{4}$ & $\mathrm{O}_{2}$ & Flow rate & $\mathrm{H}_{2} \mathrm{O}$ & Temp \\
\hline 1 & 1000 & 16 & 40 & 2 & 250 & 24 & 2000 & 14 & 20 & 2 & 300 \\
\hline 2 & 1000 & 16 & 40 & 0 & 300 & 25 & 2000 & 18 & 20 & 2 & 300 \\
\hline 3 & 1000 & 16 & 20 & 2 & 300 & 26 & 2000 & 16 & 40 & 2 & 300 \\
\hline 4 & 1000 & 14 & 40 & 2 & 300 & 27 & 2000 & 16 & 40 & 2 & 300 \\
\hline 5 & 1000 & 16 & 60 & 2 & 300 & 28 & 2000 & 18 & 60 & 2 & 300 \\
\hline 6 & 1000 & 18 & 40 & 2 & 300 & 29 & 2000 & 18 & 40 & 4 & 300 \\
\hline 7 & 1000 & 16 & 40 & 4 & 300 & 30 & 2000 & 16 & 20 & 4 & 300 \\
\hline 8 & 1000 & 16 & 40 & 2 & 350 & 31 & 2000 & 14 & 40 & 4 & 300 \\
\hline 9 & 2000 & 16 & 40 & 0 & 250 & 32 & 2000 & 16 & 60 & 4 & 300 \\
\hline 10 & 2000 & 14 & 40 & 2 & 250 & 33 & 2000 & 16 & 40 & 0 & 350 \\
\hline 11 & 2000 & 16 & 60 & 2 & 250 & 34 & 2000 & 14 & 40 & 2 & 350 \\
\hline 12 & 2000 & 18 & 40 & 2 & 250 & 35 & 2000 & 16 & 20 & 2 & 350 \\
\hline 13 & 2000 & 16 & 20 & 2 & 250 & 36 & 2000 & 18 & 40 & 2 & 350 \\
\hline 14 & 2000 & 16 & 40 & 4 & 250 & 37 & 2000 & 16 & 60 & 2 & 350 \\
\hline 15 & 2000 & 16 & 60 & 0 & 300 & 38 & 2000 & 16 & 40 & 4 & 350 \\
\hline 16 & 2000 & 14 & 40 & 0 & 300 & 39 & 3000 & 16 & 40 & 2 & 250 \\
\hline 17 & 2000 & 16 & 20 & 0 & 300 & 40 & 3000 & 16 & 40 & 0 & 300 \\
\hline 18 & 2000 & 18 & 40 & 0 & 300 & 41 & 3000 & 16 & 60 & 2 & 300 \\
\hline 19 & 2000 & 16 & 40 & 2 & 300 & 42 & 3000 & 14 & 40 & 2 & 300 \\
\hline 20 & 2000 & 16 & 40 & 2 & 300 & 43 & 3000 & 16 & 20 & 2 & 300 \\
\hline 21 & 2000 & 14 & 60 & 2 & 300 & 44 & 3000 & 18 & 40 & 2 & 300 \\
\hline 22 & 2000 & 16 & 40 & 2 & 300 & 45 & 3000 & 16 & 40 & 4 & 300 \\
\hline 23 & 2000 & 16 & 40 & 2 & 300 & 46 & 3000 & 16 & 40 & 2 & 350 \\
\hline
\end{tabular}

\section{The governing equation in AVL Boost}

The governing equations are mainly based on these following equations.

\section{Continuity equation}

$$
\frac{\partial \rho_{g}}{\partial t}=\frac{\partial \rho_{g} v_{g}}{\partial z}
$$

\section{Momentum equation}

The momentum equation in Boost uses steady-state Darcy equation for the calculation.

$$
\frac{\partial \rho}{\partial z}=-A_{D} \cdot v_{g}
$$

where $A_{D}$ is a Darcy constant 


$$
A_{D}=\phi \cdot \frac{U}{2} \cdot \frac{\rho}{d_{\text {hyd }}} \cdot \zeta=\phi \cdot \frac{1}{2} \cdot \frac{\dot{m}}{A_{\text {cross }} \cdot d_{\text {hyd }}} \cdot \zeta
$$

\section{Species equation}

$$
\begin{gathered}
\varepsilon_{g} \cdot \frac{\partial \rho \cdot w_{m}}{\partial t}=-\varepsilon_{g} \cdot \frac{\partial \rho \cdot w_{m} \cdot \mathrm{U}}{\partial z} \\
+\varepsilon_{g} \cdot \frac{\partial}{\partial z}\left(\rho g \cdot D_{e f f} \cdot \frac{\partial w_{m, g}}{\partial z}\right) \\
+M_{m, g} \cdot \sum_{n}^{N} v_{n, m} \cdot \dot{r}_{n}\left(C_{m}, T_{s}\right)
\end{gathered}
$$

\section{Energy equation}

The energy conversation equation in gas phase can be seen in the equation below.

$$
\begin{gathered}
\varepsilon_{g} \cdot \frac{\partial}{\partial t}\left(\rho_{g} \cdot \sum_{m}^{M} w_{m, g} \cdot h_{m}\right)= \\
-\varepsilon_{g} \cdot \frac{\partial}{\partial z}\left(\rho_{g} \cdot \sum_{m}^{M} w_{m, g} \cdot h_{m} \cdot v_{g}\right)+\varepsilon_{g} \cdot \frac{\partial}{\partial z}\left(\lambda_{g} \cdot \frac{\partial T_{g}}{\partial z}\right) \\
+\sum_{m}^{M} \varepsilon_{g} \cdot \frac{\partial}{\partial z}\left(\rho_{g} \cdot D_{e f f} \cdot \frac{\partial w_{m, g}}{\partial z} \cdot h_{m}\right) \\
+G S A \cdot k_{h} \cdot\left(T_{s}-T_{g}\right)-\sum_{n}^{N} \Delta h_{n} \cdot \dot{r}_{n}\left(C_{m}, T_{s}\right)
\end{gathered}
$$

The solid phase energy balance equation is as follows.

$$
\begin{gathered}
\left(1-\varepsilon_{g}\right) \cdot \rho_{s} \cdot \frac{\partial\left(c_{p, s} \cdot T_{s}\right)}{\partial t}=\left(1-\varepsilon_{g}\right) \cdot \frac{\partial}{\partial z}\left(\lambda_{s} \cdot \frac{\partial T_{s}}{\partial z}\right) \\
-G S A \cdot k_{h} \cdot\left(T_{s}-T_{g}\right)+\sum_{n}^{N} \Delta h_{n} \cdot \dot{r}_{n}\left(C_{m}, T_{s}\right)+\dot{q}_{e x t}
\end{gathered}
$$

$\dot{r}_{i}\left(C_{m}, T_{s}\right)$ is a molar reaction rate of the reaction in the DOC. The calculation for this term is done by the new proposed kinetic model. Other information can be found in AVL Boost manual The kinetic model employed in this current research study is a reduced model that is based on Langmuir-Hinshelwood mechanism found in ${ }^{23,24)}$ for multiple species in the exhaust gas.

$\mathrm{C}_{3} \mathrm{H}_{8}$ Oxidation Mechanisms

$$
\begin{gathered}
C_{3} H_{8}+2 \theta_{V} \rightarrow \theta_{C 3 H 6}+\theta_{H 2} \\
\theta_{C 3 H 6}+\theta_{V} \rightarrow \theta_{C 2 H 4}+\theta_{C H 2} \\
\theta_{C 2 H 4}+\theta_{V} \rightarrow 2 \theta_{C H 2} \\
\theta_{C H 2}+3 \theta_{O} \rightarrow \mathrm{CO}_{2}+H_{2} \mathrm{O} \\
\theta_{H 2}+\theta_{O} \rightarrow \mathrm{H}_{2} \mathrm{O}
\end{gathered}
$$

\section{$\mathrm{CH}_{4}$ Oxidation Mechanisms}

$$
\begin{gathered}
\mathrm{CH}_{4}+2 \theta_{V} \rightarrow \theta_{C H 3}+\theta_{H} \\
\theta_{C H 3}+\theta_{V} \rightarrow \theta_{C H 2}+\theta_{H} \\
2 \theta_{H}+\theta_{O} \rightarrow \mathrm{H}_{2} \mathrm{O} \\
\theta_{\mathrm{CH} 2}+3 \theta_{O} \rightarrow \mathrm{CO}_{2}+\mathrm{H}_{2} \mathrm{O}
\end{gathered}
$$

\section{CO Oxidation Mechanisms}

$$
\begin{aligned}
\mathrm{CO}+\theta_{V} & \rightarrow \theta_{C O} \\
\theta_{C O}+\theta_{O} & \rightarrow \mathrm{CO}_{2}
\end{aligned}
$$

\section{Kinetic model}

The kinetic models and reaction steps are in the equations below.

$$
\begin{aligned}
& 1=\theta_{C O}+\theta_{H 2}+\theta_{C 3 H 6}+\theta_{C 2 H 4}+\theta_{C H 2}+\theta_{C H 4} \\
& +\theta_{\mathrm{CH} 3}+\theta_{\mathrm{CH} 2 \mathrm{M}}+\theta_{\mathrm{H}}+\theta_{\mathrm{H} 2 \mathrm{O}} \\
& +\theta_{O}+\theta_{V} \\
& \theta_{C O}=K_{C O} C_{C O} \theta_{V} \\
& \theta_{\mathrm{CH} 4}=K_{\mathrm{CH} 4} C_{\mathrm{CH} 4} \theta_{\mathrm{V}} \\
& \theta_{\mathrm{CH} 3}=\frac{2 K_{\mathrm{CH} 4} C_{\mathrm{CH} 4} \theta_{V}}{K_{\mathrm{CH} 3}} \\
& \theta_{H}=K_{C H 3} \theta_{V} \\
& \theta_{\mathrm{CH} 2 \mathrm{M}}=\frac{2 K_{\mathrm{CH} 4} C_{\mathrm{CH} 4} \theta_{V}}{K_{\mathrm{CH} 3}} \\
& \theta_{O}=\sqrt{K_{O} C_{O 2}} \theta_{V} \\
& \theta_{\mathrm{C} 3 \mathrm{H} 6}=\frac{2 K_{\mathrm{C} 3 \mathrm{H} 8} C_{\mathrm{C} 3 \mathrm{H} 8} \theta_{V}}{K_{\mathrm{C} 3 \mathrm{H} 6}} \\
& \theta_{\mathrm{C} 2 \mathrm{H} 4}=\frac{2\left(K_{\mathrm{C} 3 \mathrm{H} 8} K_{\mathrm{C} 2 \mathrm{H} 4} C_{\mathrm{C} 3 \mathrm{H} 8}\right)^{\frac{2}{3}} \theta_{V}}{K_{\mathrm{C} 2 \mathrm{H} 4}} \\
& \theta_{\mathrm{CH} 2}=\left(K_{\mathrm{C} 3 \mathrm{H} 8} K_{\mathrm{C} 2 \mathrm{H} 4} C_{\mathrm{C} 3 \mathrm{H} 8}\right)^{\frac{1}{3}} \theta_{V} \\
& \theta_{H 2}=K_{C 3 H 6} \theta_{V} \\
& \theta_{H 2 O}=K_{H 2 O} \theta_{V} \\
& G=K_{\mathrm{CO}} C_{\mathrm{CO}}+K_{\mathrm{CH} 4} C_{\mathrm{CH} 4}+\frac{2 K_{\mathrm{CH} 4} C_{\mathrm{CH} 4}}{K_{\mathrm{CH} 3}}+K_{\mathrm{CH} 3} \\
& +\frac{2 K_{C H 4} C_{C H 4}}{K_{C H 3}}+\sqrt{K_{O} C_{O 2}} \\
& +\frac{2 K_{C 3 H 8} C_{C 3 H 8} \theta_{V}}{K_{C 3 H 6}} \\
& +\frac{2\left(K_{C 3 H 8} K_{C 2 H 4} C_{C 3 H 8}\right)^{\frac{2}{3}} \theta_{V}}{K_{C 2 H 4}} \\
& +\left(K_{\mathrm{C} 3 \mathrm{H} 8} K_{\mathrm{C} 2 \mathrm{H} 4} C_{\mathrm{C} 3 \mathrm{H} 8}\right)^{\frac{1}{3}} \\
& +K_{\mathrm{C} 3 \mathrm{H} 6}+K_{\mathrm{H} 2 \mathrm{O}} \\
& \theta_{V}=\frac{1}{1+G}
\end{aligned}
$$

The rate determining steps are in the equation (10), (15) and (17) for $\mathrm{C}_{3} \mathrm{H}_{8}, \mathrm{CH}_{4}$ and $\mathrm{CO}$ respectively. The reaction rate equations for $\mathrm{CO}, \mathrm{CH}_{4}$, and $\mathrm{C}_{3} \mathrm{H}_{8}$ are in equation (32) to (34).

$$
\begin{gathered}
r_{C O}=K_{R C O} \theta_{C O} \theta_{O} \\
r_{C H 4}=3 K_{R C H 4} \theta_{C H 2 M} \theta_{O}{ }^{3} \\
r_{C 3 H 8}=3 K_{R C 3 H 8} \theta_{C H 2} \theta_{O}{ }^{3}
\end{gathered}
$$

The reaction rate equations are then derived into the equation (35) to (37).

$$
\begin{aligned}
& r_{C O}=K_{R C O} K_{C O} K_{O}{ }^{\frac{1}{2}} C_{C O} C_{O}^{\frac{1}{2}}\left[\frac{1}{1+G}\right]^{2} \\
& r_{\mathrm{CH} 4}=6 \frac{K_{\mathrm{RCH} 4} K_{\mathrm{CH} 4} K_{O}{ }^{\frac{3}{2}}}{K_{\mathrm{CH} 3}} C_{\mathrm{CH} 4} C_{O} \frac{3}{2}\left[\frac{1}{1+G}\right]^{4} \\
& r_{C 3 H 8}=3 \frac{K_{R C 3 H 8} K_{C 3 H 8}{ }^{\frac{1}{3}} K_{C 2 H 4}{ }^{\frac{1}{3}} K_{O}{ }^{\frac{3}{2}}}{K_{C H 3}} \ldots \\
& +C_{C 3 H 8^{\frac{1}{3}}} C_{O}{ }^{\frac{3}{2}}\left[\frac{1}{1+G}\right]^{4}
\end{aligned}
$$

In $\mathrm{CO}$ reaction rate equation, the term $\mathrm{G}$ was reduced to the equation (38). 


$$
\begin{aligned}
G=K_{C O} C_{C O}+ & K_{C H 4} C_{C H 4}+\frac{2 K_{C H 4} C_{C H 4}}{K_{C H 3}}+K_{C H 3} \\
& +\frac{2 K_{C H 4} C_{C H 4}}{K_{C H 3}}+\sqrt{K_{O} C_{O 2}} \\
& +\frac{2 K_{C 3 H 8} C_{C 3 H 8} \theta_{V}}{K_{C 3 H 6}} \\
& +\frac{2\left(K_{C 3 H 8} K_{C 2 H 4} C_{C 3 H 8}\right)^{\frac{2}{3}} \theta_{V}}{K_{C 2 H 4}} \\
& +\left(K_{C 3 H 8} K_{C 2 H 4} C_{C 3 H 8}\right)^{\frac{1}{3}}+K_{C 3 H 6}
\end{aligned}
$$

The rate constant $\mathrm{K}_{\mathrm{k}}$ is computed by the Arrhenius equation as in the equation (39).

$$
K_{m}=A_{m} \exp \left(\frac{-E a_{m}}{R T_{s}}\right)
$$

The benefit of using the above equations is that water concentration has been taken into the account on $\mathrm{CH}_{4}$ oxidation which is never included in the conventional kinetic models in the software package. Details of employing this simulation to study $\mathrm{CH}_{4}$ oxidation can be found in ${ }^{(25)}$.

\section{Experiment results}

Results for $\mathrm{CH}_{4}$ conversion efficiency for all cases in DOE are shown in Fig. 6. $\mathrm{CH}_{4}$ conversion efficiency is calculated based on $\mathrm{CH}_{4}$ measurements before and after DOC. It is shown from Fig. 6 that experimental data covers $\mathrm{CH}_{4}$ conversion efficiency from 10 to $90 \%$. This data set is, therefore, suitable for optimization analysis. Fig. 7 depicts Box Plots analysis that shows relationships of $\mathrm{CH}_{4}$ conversion efficiency with each main factors. From Fig. 7, it is clearly seen that $\mathrm{CH}_{4}$ and $\mathrm{O}_{2}$ concentrations do not effect $\mathrm{CH}_{4}$ oxidation rate. This is because of all three levels of each factors: 1000,2000 , and $3000 \mathrm{ppmC}$ for $\mathrm{CH}_{4}$ and $14,16,18 \%$ for $\mathrm{O}_{2}$, there is no significant trend on changes in $\mathrm{CH}_{4}$ conversion efficiency. These differences are only within $15 \%$. However, flow rate, $\mathrm{H}_{2} \mathrm{O}$ concentration, and temperature are considered as main factors for $\mathrm{CH}_{4}$ oxidation rate.

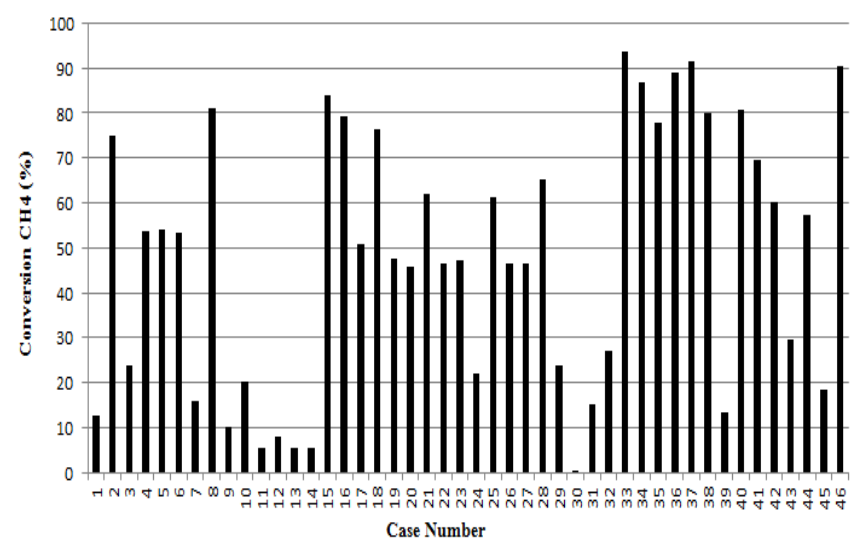

Fig. 6. $\mathrm{CH}_{4}$ Conversion Efficiency for All Cases in Table 3

Experimental data show that three levels of these factors significantly impact $\mathrm{CH}_{4}$ conversion efficiency. Significant trends of changes can be observed. Increasing temperature (Case 1 vs 8 ) and decreasing $\mathrm{H}_{2} \mathrm{O}$ concentration (Case 2 vs 7 ) help increasing $\mathrm{CH}_{4}$ conversion efficiency as seen in ${ }^{(17,19)}$. In addition, increasing flow rate (Case 3 vs 5) help increasing $\mathrm{CH}_{4}$ conversion efficiency as well. In most literatures, as the space velocity becomes higher, the DOC conversion efficiency is lessening but some experimental researches argues that the conversion efficiency increases alongside with the space velocity to the certain point before starting to decrease. The researchers conclude that, the higher space velocity favors the formation of the intermediate species $(26,27)$. Table 4 shows P-values and coefficient of determinations $\left(R^{2}, R^{2}\right.$ Adj $)$ of all five factors and their interactions in four optimization mathematical models, namely, Full Quadratic, Linear + Interaction, Linear + Squares, and Linear with the confidence level of $95 \%$. More details of these four mathematical models can be found in ${ }^{(28)}$.
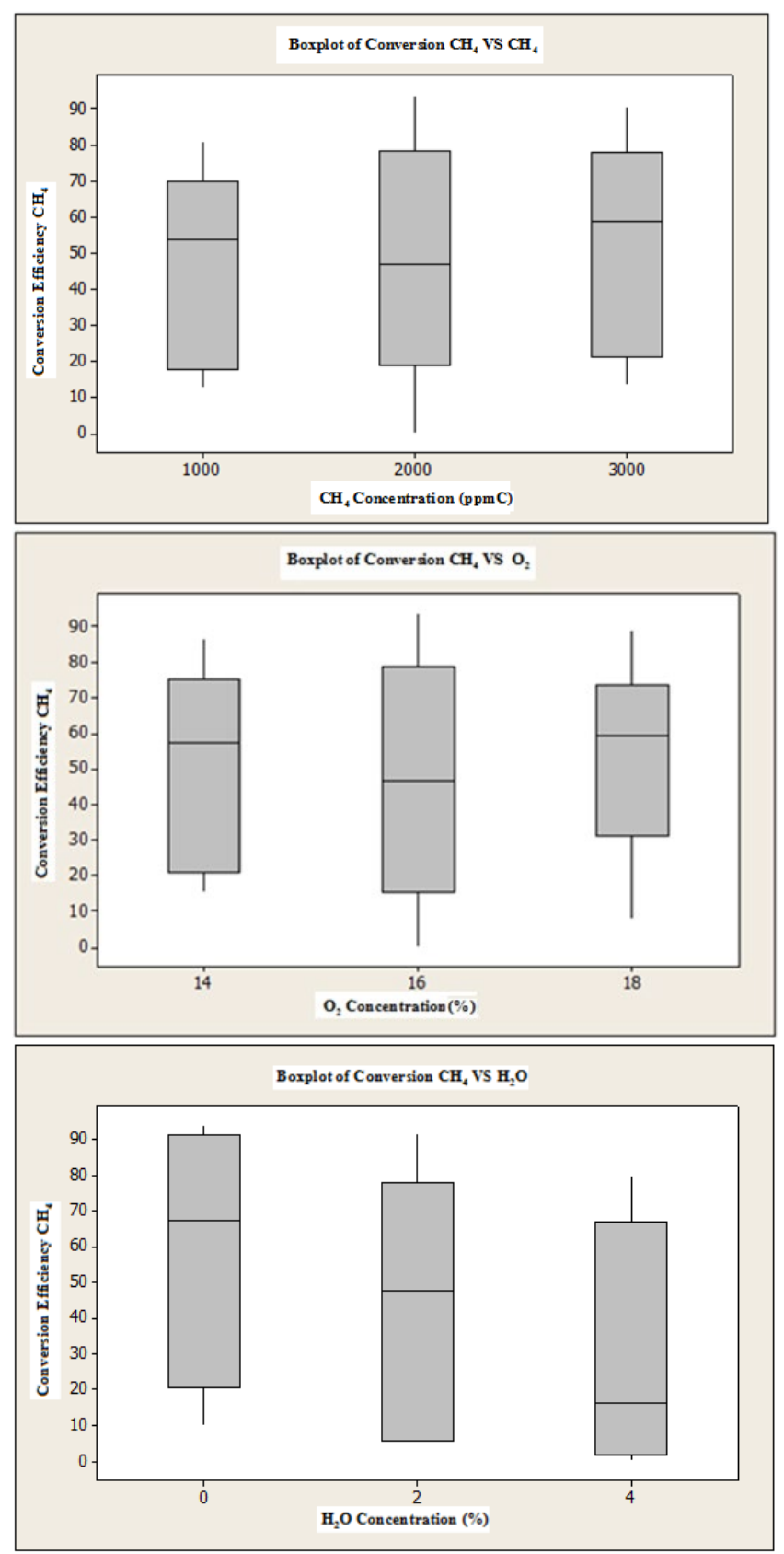


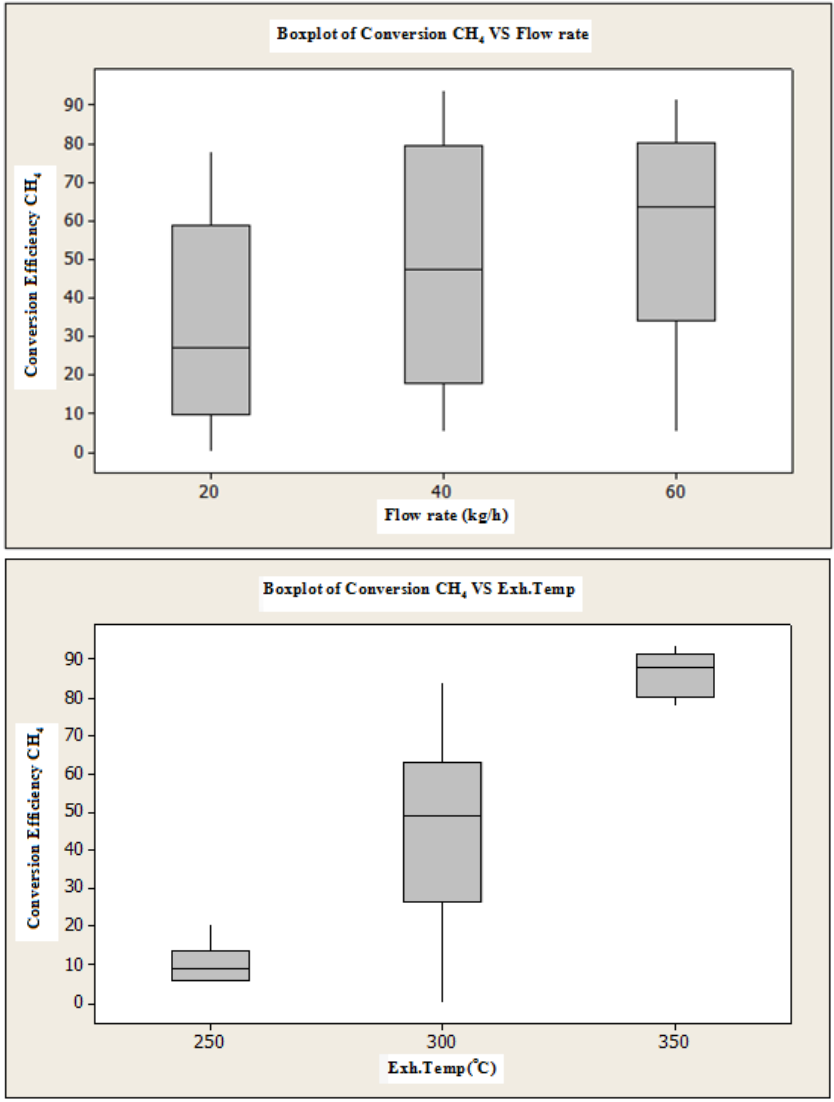

Fig. 7. Box Plots between $\mathrm{CH}_{4}$ Conversion Efficiency and Each Main Factors

After performing analysis based on all mathematical models, it is found out that only flow rate, $\mathrm{H}_{2} \mathrm{O}$ concentration, and temperature give $\mathrm{P}$-Value $<\alpha(\alpha=0.05)$. These means that only these three factors impact $\mathrm{CH}_{4}$ conversion efficiency individually. Interactions among five main factors from DOE give P-Value $>\alpha$ $(\alpha=0.05)$ and therefore, do not show any significant effect. The values of $\mathrm{R}^{2}, \mathrm{R}^{2}$ Adj are relatively high for all mathematical models $(>90 \%)$ but the values of Lack-of-Fit which determine the sufficiency of variables in an equation is not suitable since P-Value $<\alpha(\alpha=0.05)$. Therefore, designed mathematical models based on this set of data is not suitable to predict $\mathrm{CH}_{4}$ conversion efficiency. There are two methodologies to solve this issue. It is either increase or decrease main factors depending on the topic or methodology of the research interest ${ }^{(28)}$.

Results based on selected cases from Fig. 6. It can be clearly seen that only three main factors: flow rate, $\mathrm{H}_{2} \mathrm{O}$ concentration, and temperature changes impact on catalytic $\mathrm{CH}_{4}$ oxidation ${ }^{(17)}$. Now only these three main factors are used to design DOE again. Fifteen experiments based on Box-Behnken methodology are listed in Table 5 which is a more compact version of experiments shown in Table 3.

Repeating the methodology done previously in Fig. 6-7 and Table 4, P-values and coefficient of determinations $\left(\mathrm{R}^{2}, \mathrm{R}^{2}\right.$ Adj $)$ of all three factors and their interactions in four optimization mathematical models are shown in Table 6.
Table 4. P-Values of All Five Factors Analysis in Four Optimization Mathematical Models

\begin{tabular}{|c|c|c|c|c|}
\hline \multirow[t]{2}{*}{ Factor } & \multicolumn{4}{|c|}{ P-value } \\
\hline & $\begin{array}{l}\text { Full } \\
\text { Quadratic }\end{array}$ & $\begin{array}{l}\text { Linear }+ \\
\text { Interaction }\end{array}$ & $\begin{array}{l}\text { Linear + } \\
\text { Squares }\end{array}$ & $\begin{array}{l}\text { Linea } \\
\mathrm{r}\end{array}$ \\
\hline $\mathrm{CH}_{4}$ & 0.254 & 0.256 & 0.213 & 0.220 \\
\hline $\mathrm{O}_{2}$ & 0.415 & 0.417 & 0.374 & 0.382 \\
\hline Flow rate & 0.000 & 0.000 & 0.000 & 0.000 \\
\hline $\mathrm{H}_{2} \mathrm{O}$ & 0.000 & 0.000 & 0.000 & 0.000 \\
\hline Temp & 0.000 & 0.000 & 0.000 & 0.000 \\
\hline $\mathrm{CH}_{4} * \mathrm{CH}_{4}$ & 0.536 & - & 0.500 & - \\
\hline $\mathrm{O}_{2} * \mathrm{O}_{2}$ & 0.111 & - & 0.081 & - \\
\hline $\begin{array}{l}\text { Flow rate* } \\
\text { Flow rate }\end{array}$ & 0.460 & - & 0.421 & - \\
\hline $\mathrm{H}_{2} \mathrm{O} * \mathrm{H}_{2} \mathrm{O}$ & 0.533 & - & 0.497 & - \\
\hline $\begin{array}{l}\text { Temp* } \\
\text { Temp }\end{array}$ & 0.847 & - & 0.834 & - \\
\hline $\mathrm{CH}_{4} * \mathrm{O}_{2}$ & 0.907 & 0.907 & - & - \\
\hline $\begin{array}{l}\mathrm{CH}_{4} * \text { Flow } \\
\text { rate }\end{array}$ & 0.657 & 0.659 & - & - \\
\hline $\mathrm{CH}_{4} * \mathrm{H}_{2} \mathrm{O}$ & 0.881 & 0.882 & - & - \\
\hline $\begin{array}{l}\mathrm{CH}_{4} * \\
\text { Temp }\end{array}$ & 0.685 & 0.687 & - & - \\
\hline $\begin{array}{ll}\mathrm{O}_{2} * & \text { Flow } \\
\text { rate } & \\
\end{array}$ & 0.103 & 0.104 & - & - \\
\hline $\mathrm{O}_{2} * \mathrm{H}_{2} \mathrm{O}$ & 0.600 & 0.602 & - & - \\
\hline $\mathrm{O}_{2} *$ Temp & 0.496 & 0.498 & - & - \\
\hline $\begin{array}{l}\text { Flow rate* } \\
\mathrm{H}_{2} \mathrm{O}\end{array}$ & 0.776 & 0.777 & - & - \\
\hline $\begin{array}{l}\text { Flow rate* } \\
\text { Temp }\end{array}$ & 0.532 & 0.534 & - & - \\
\hline $\begin{array}{l}\mathrm{H}_{2} \mathrm{O}^{*} \\
\text { Temp }\end{array}$ & 0.671 & 0.673 & - & - \\
\hline $\begin{array}{l}\text { Lack-of- } \\
\text { Fit }\end{array}$ & 0.000 & 0.000 & 0.000 & 0.000 \\
\hline $\mathrm{R}^{2}(\%)$ & 92.53 & 90.9 & 91.13 & 89.5 \\
\hline $\mathrm{R}_{\text {Adj }}^{2}(\%)$ & 86.56 & 86.35 & 86.6 & 88.19 \\
\hline
\end{tabular}

Table 5. DOE for Three Chosen Parameters According to BoxBehnken Design

\begin{tabular}{|c|c|c|c|}
\hline $\begin{array}{c}\text { Case } \\
\text { number }\end{array}$ & $\begin{array}{c}\text { Flow rate } \\
(\mathbf{k g} / \mathbf{h r})\end{array}$ & $\mathbf{H}_{\mathbf{2}} \mathbf{O}(\mathbf{\%})$ & $\begin{array}{c}\text { Temperature } \\
\left({ }^{\circ} \mathbf{C}\right)\end{array}$ \\
\hline 1 & 40 & 0 & 350 \\
\hline 2 & 40 & 4 & 350 \\
\hline 3 & 40 & 4 & 250 \\
\hline 4 & 40 & 2 & 300 \\
\hline 5 & 60 & 2 & 250 \\
\hline 6 & 60 & 0 & 300 \\
\hline 7 & 40 & 2 & 300 \\
\hline 8 & 20 & 0 & 300 \\
\hline 9 & 60 & 2 & 350 \\
\hline 10 & 20 & 2 & 350 \\
\hline 11 & 20 & 2 & 250 \\
\hline 12 & 20 & 4 & 300 \\
\hline 13 & 40 & 0 & 250 \\
\hline 14 & 60 & 4 & 300 \\
\hline 15 & 40 & 2 & 300 \\
\hline
\end{tabular}


Table 6. P-Values of All Three Factors Analysis in Four Optimization Mathematical Models

\begin{tabular}{|l|l|l|l|l|}
\hline \multirow{2}{*}{ Factor } & \multicolumn{4}{|c|}{ P-value } \\
\cline { 2 - 5 } & $\begin{array}{l}\text { Full } \\
\text { Quadratic }\end{array}$ & $\begin{array}{l}\text { Linear }+ \\
\text { Interaction }\end{array}$ & $\begin{array}{l}\text { Linear }+ \\
\text { Squares }\end{array}$ & Linear \\
\hline Flow rate & 0.850 & 0.823 & 0.300 & 0.049 \\
\hline $\mathrm{H}_{2} \mathrm{O}$ & 0.896 & 0.981 & 0.534 & 0.003 \\
\hline Temp & 0.867 & 0.056 & 0.791 & 0.000 \\
\hline $\begin{array}{l}\text { Flow rate* } \\
\text { Flow rate }\end{array}$ & 0.551 & - & 0.454 & - \\
\hline $\mathrm{H}_{2} \mathrm{O}^{*} \mathrm{H}_{2} \mathrm{O}$ & 0.720 & - & 0.653 & - \\
\hline $\begin{array}{l}\text { Temp* } \\
\text { Temp }\end{array}$ & 0.872 & - & 0.840 & - \\
\hline $\begin{array}{l}\text { Flow rate* } \\
\mathrm{H}_{2} \mathrm{O}\end{array}$ & 0.857 & 0.825 & - & - \\
\hline $\begin{array}{l}\text { Flow rate* } \\
\text { Temp }\end{array}$ & 0.693 & 0.629 & - & - \\
\hline $\begin{array}{l}\mathrm{H}_{2} \mathrm{O} \\
\text { Temp }\end{array}$ & 0.788 & 0.742 & - & - \\
\hline Lack-of-Fit & 0.042 & 0.074 & 0.078 & 0.104 \\
\hline $\mathrm{R}^{2}$ (\%) & 92.24 & 91.35 & 91.79 & 90.89 \\
\hline $\mathrm{R}^{2}$ Adj $(\%)$ & 78.28 & 84.85 & 85.63 & 88.41 \\
\hline
\end{tabular}

From Table 6, considering P-values of each mathematical models for three main factors and their interactions, only Linear-type model is suitable because $\mathrm{P}$-values $<\alpha(\alpha=0.05)$ with $\mathrm{R}^{2}=90.89$ $\%$ and $\mathrm{R}^{2}$ Adj $=88.41 \%$. This indicates that this model satisfies Regression analysis with $\mathrm{P}-$ Value $=0.000$ in which, at least there is one parameter that effect $\mathrm{CH}_{4}$ conversion efficiency. P-values of Lack-of-Fit are higher than $\alpha(\alpha=0.05)$. Thus, this mathematical model is sufficient to predict $\mathrm{CH}_{4}$ conversion efficiency. Coefficients of the Linear-type equation model are listed in Table 7. And finally, we obtain the equation to predict $\mathrm{CH}_{4}$ conversion efficiency as shown in Equation (40).

Table 7. Coefficients of Each Factors from Linearized Regression Analysis

\begin{tabular}{|l|c|}
\hline \multicolumn{1}{|c|}{ Term } & Coefficient \\
\hline Constant & -195.016 \\
\hline Flow rate $(\mathrm{kg} / \mathrm{hr})$ & 0.459 \\
\hline $\mathrm{H}_{2} \mathrm{O}(\%)$ & -7.867 \\
\hline Exh.Temp $\left({ }^{\circ} \mathrm{C}\right)$ & 0.792 \\
\hline
\end{tabular}

$\mathrm{Y}=-195.016+0.459 *$ (Flow rate $)-7.866 *\left(\mathrm{H}_{2} \mathrm{O}\right)+$ $0.792 *($ Exh.Temp)

\section{Correctness Test of DOE}

Correctness test of data from DOE is one of the most important processes in order to confirm the validity of obtained experimental data. Fig. 8 shows that the experimental data in the current work is correct and reliable. This can be seen from the residuals graph that follows $\varepsilon_{i j} \approx N I D\left(O, \sigma^{2}\right)$ principle. That is, residuals has normal distribution characteristics as seen from a set of experimental data that is linearized independent (top figure) which cannot predict in any forms as the average value is not equal to zero (middle figure). Lastly, the variance of the data $\left(\sigma^{2}\right)$ is constant (bottom figure).

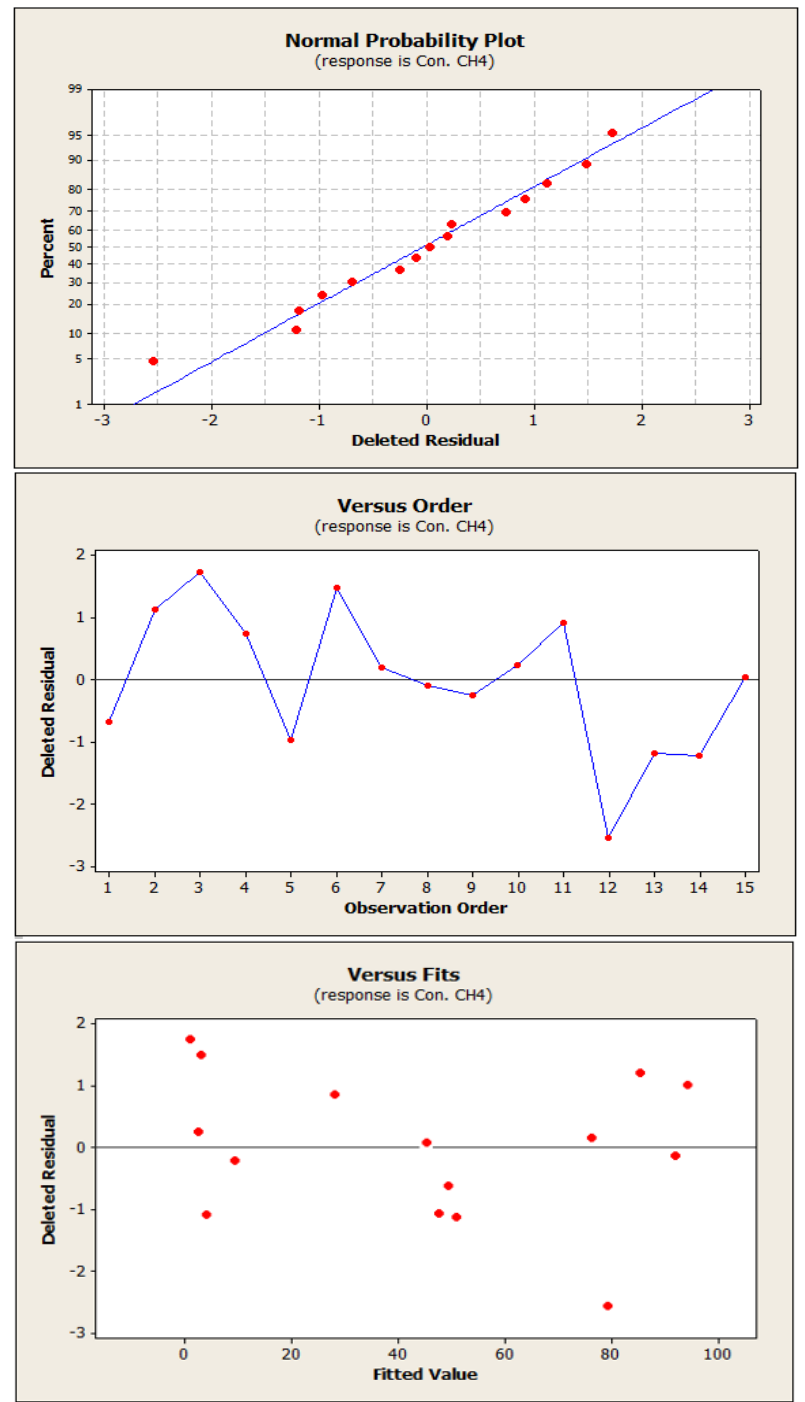

Fig. 8. Correctness of Residuals Distribution (top figure), Data Independency (middle figure), and Data Variance (bottom figure)

\section{Simulation Results}

The kinetic models employed in AVL Boost are calibrated based on light-off experiments. $\mathrm{CH}_{4}$ is fed into the Synthetic Exhaust Gas Generating System as shown in Figure1. The temperature is ramping up with $20^{\circ} \mathrm{C}$ between each ramp. At each temperature, $2,000 \mathrm{ppm}$ of $\mathrm{CH}_{4}$ was fed for 120 seconds before the data is recorded. The flow rate of the gas is at the space velocity of 22,850 $\mathrm{hr}^{-1}$. The light-off temperature tests are repeated on $\mathrm{CO}$ and $\mathrm{C}_{3} \mathrm{H}_{8}$. The concentrations for each following tests are 1,500 and 1,000, respectively. An example of a comparison between the experimental data and the calibrated kinetic model in AVL Boost is shown in Fig.9 for $\mathrm{CH}_{4}$ oxidation. Good agreements between experimental and simulated data can be clearly seen. All kinetic parameters used in the current study are listed in (25). 


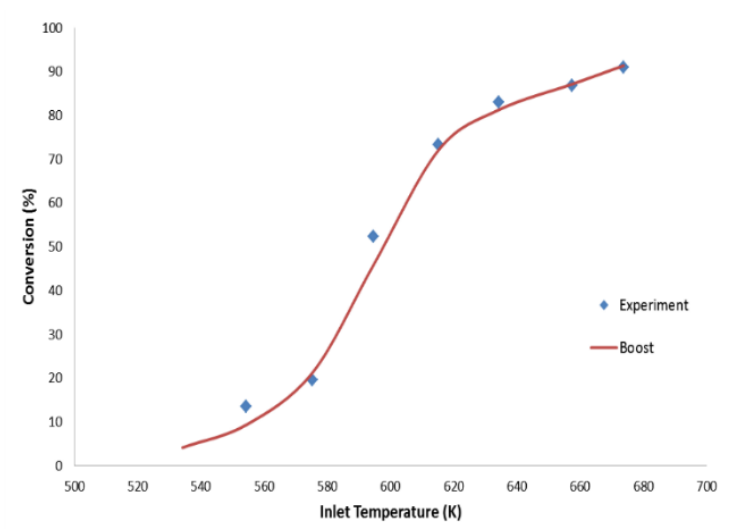

Fig. 9. $\mathrm{CH}_{4}$ light-off temperature, Experiment vs AVL Boost

Fifteen cases as seen in Table 5 are predicted by using AVL Boost. Comparisons among experimental data, kinetic models from AVL Boost, and DOE Model (eq 40) are employed and shown in Fig. 10. Based on these results, both AVL Boost and DOE Model give similar trends comparing to experimental data. Regression plots comparing between AVL Boost with experimental data (Fig. 11) and DOE Model with experimental data (Fig. 12) are shown below. It is seen that based on the R-square and $\mathrm{R}$-square adjusted value, DOE Model predicts $\mathrm{CH}_{4}$ conversion efficiency better than AVL Boost with less computational resources. The values of R-square and R-square adjusted for DOE Model are more than $90 \%$.

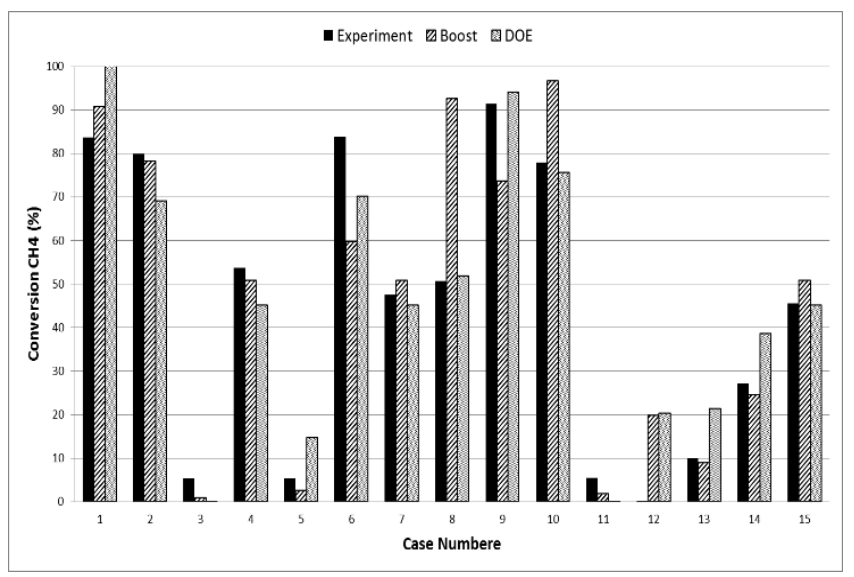

Fig. 10. Comparisons of experimental data vs AVL Boost vs DOE model (eq.40)

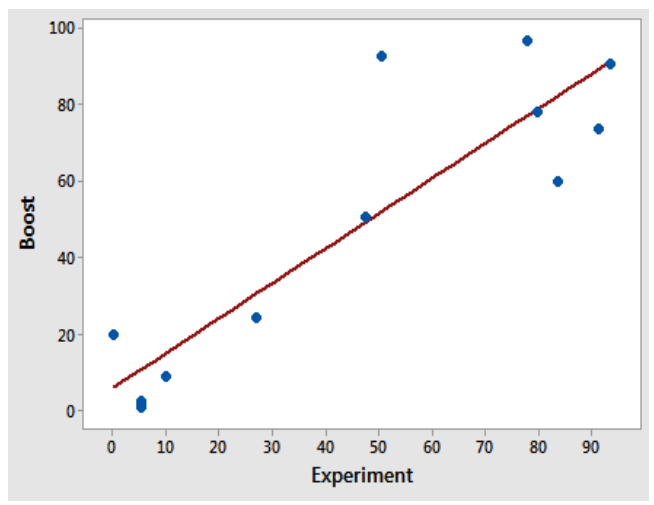

Fig. 11. Regression Plot of $\mathrm{CH}_{4}$ Conversion Efficiency (\%) between AVL Boost and Experimental Data with $\mathrm{R}^{2}=80.8$ and $\mathrm{R}^{2} \mathrm{Adj}=79.4$

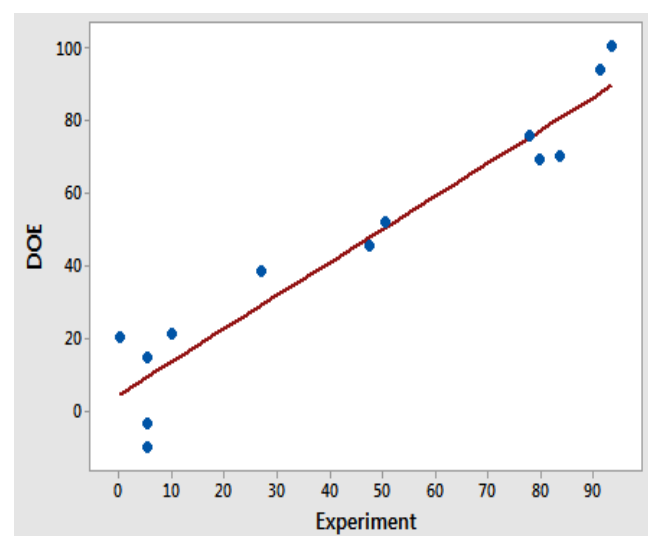

Fig. 12. Regression Plot of $\mathrm{CH}_{4}$ Conversion Efficiency (\%) between DOE Model and Experimental Data with $\mathrm{R}^{2}=91.2$ and

$$
\mathrm{R}^{2} \mathrm{Adj}=90.6
$$

\section{Optimization $\mathrm{CH}_{4}$ Oxidation Exhaust Conditions}

One of the benefits of generating DOE Model (eq 40) is to perform an optimization. Proper exhaust conditions can then simulated for yielding best $\mathrm{CH}_{4}$ oxidation environment. Even though this task can also be done with AVL Boost, one can see that the Linearized Regression Analysis is easier to achieve the same task with less efforts. Three contour plots that show relationship among three main factors in DOE Model can be seen in Fig. 13. Fig. 13 helps us to clearly see that in order to yield best $\mathrm{CH}_{4}$ conversion efficiency, as high as $80 \%$, high exhaust temperature with high exhaust flow rate as well as less water concentration are preferable (dark areas in all contour plots). It strongly suggests that not only exhaust temperature and water concentration as seen in most past literatures effect $\mathrm{CH}_{4}$ oxidation, but also the exhaust flow rate. However, relationships among each main factors are linearized regression. No interactions among these main factors are observed in the current study.

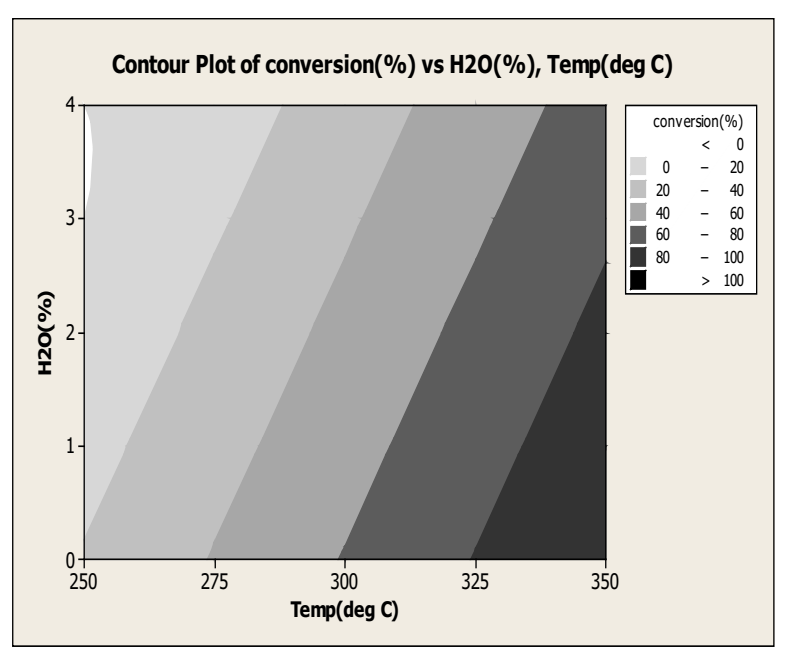



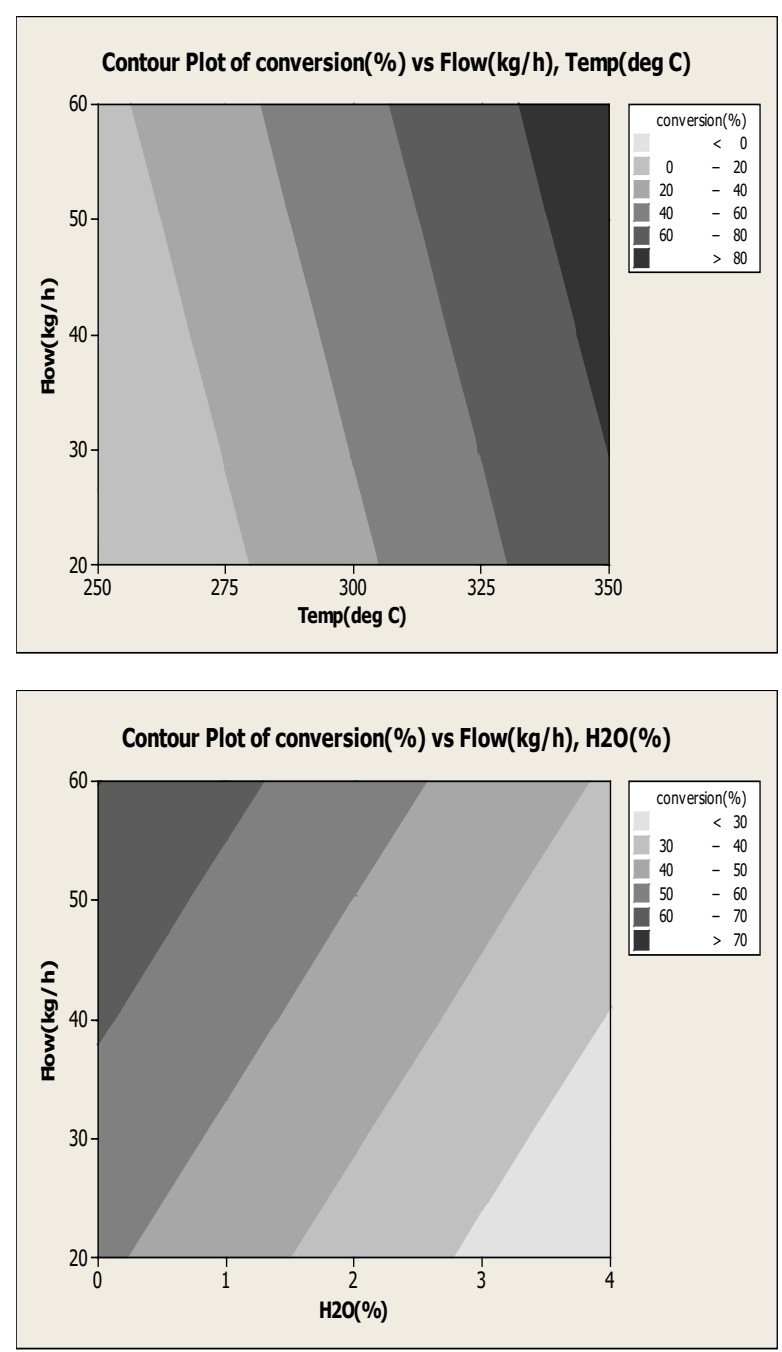

Fig. 13. Contour Plots of Relationships Among Each Main Factors in DOE Model

By using Response Optimization Function in Minitab, it is found out that the flow rate of $60 \mathrm{~kg} / \mathrm{hr}, \mathrm{H}_{2} \mathrm{O}$ concentration of $1.16 \%$, and the exhaust temperature of $350^{\circ} \mathrm{C}$ yield $99.9 \%$ of $\mathrm{CH}_{4}$ conversion efficiency as shown in Fig. 14 which depicts optimum points of each main factors generated by DOE Model. By adjusting $\mathrm{H}_{2} \mathrm{O}$ concentration in Figure 14 between 3 and 4\% (typical lean exhaust conditions), while holding another parameters constant, $\mathrm{CH}_{4}$ conversion efficiencies are ranged between $78-86 \%$.

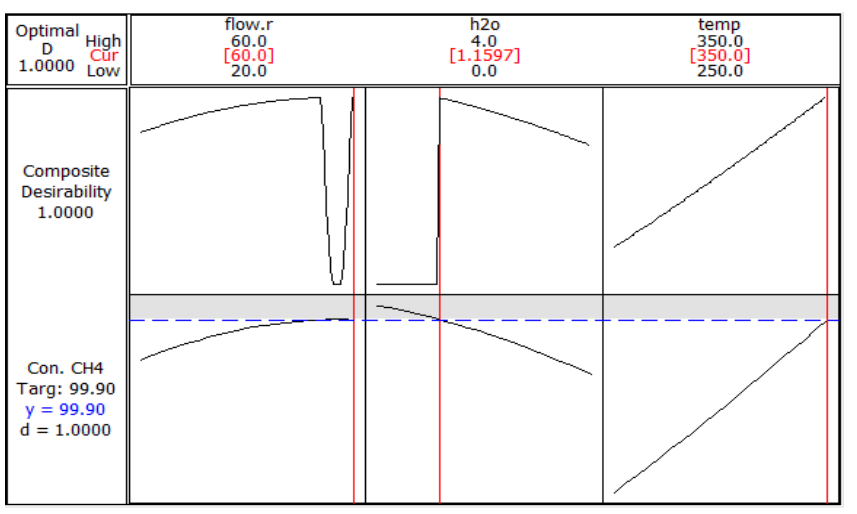

Fig. 14. Optimization Points of Each Main Factors

\section{Conclusion}

In this work, factors that are chosen to investigate $\mathrm{CH}_{4}$ oxidation in DOC coupled to DF-PCCI engine are $\mathrm{CH}_{4} / \mathrm{O}_{2} / \mathrm{H}_{2} \mathrm{O}$ concentrations, exhaust flow rate, and exhaust temperature. Experiments are done on a Synthetic Exhaust Gas Generating System. Flow conditions are mimic to DF-PCCI exhaust-like. The conclusions are drawn as follows.

1. Exhaust temperature, exhaust flow rate, and $\mathrm{H}_{2} \mathrm{O}$ concentration are major factors that influence $\mathrm{CH}_{4}$ conversion efficiency. Interactions among these factors provide no effect on $\mathrm{CH}_{4}$ conversion efficiency.

2. By considering each factor individually in the experiments with the new tested DOC, the minimum exhaust temperature sufficient to oxidize $\mathrm{CH}_{4}$ is at $350^{\circ} \mathrm{C}$. High exhaust flow rate also helps increasing $\mathrm{CH}_{4}$ conversion efficiency. However, $\mathrm{H}_{2} \mathrm{O}$ concentration is a major inhibit factor for $\mathrm{CH}_{4}$ oxidation.

3. The DOE model of predicting $\mathrm{CH}_{4}$ conversion efficiency is equal to $-195.016+0.459 *$ Flow rate $(\mathrm{kg} / \mathrm{hr})-$ $7.867 * \mathrm{H}_{2} \mathrm{O}(\%)+0.792 *$ Exh.Temp. $\left({ }^{\circ} \mathrm{C}\right)$.

4. Kinetic models in AVL Boost and DOE Model are compared to experimental data. DOE Model yields a better fit to experimental data with less computational resources and efforts.

5. From Response Optimization analysis, to reach $\mathrm{CH}_{4}$ conversion efficiency of more than $99.9 \%$, the exhaust temperature, exhaust flow rate, and $\mathrm{H}_{2} \mathrm{O}$ concentration should be controlled at $350^{\circ} \mathrm{C}, 60 \mathrm{~kg} / \mathrm{hr}$, and $1.16 \%$, respectively. However, with $\mathrm{H}_{2} \mathrm{O}$ concentration between 3 and $4 \%$ (typical lean exhaust conditions), $\mathrm{CH}_{4}$ conversion efficiencies are ranged between $78-86 \%$.

\section{Acknowledgement}

This work is financially supported by PTT Research and Technology Institute and The Thailand Research Fund (TRF) via Research and Researcher for Industry (RRi) Contract No. PHD56I0049. Special thanks go to The Graduate School, Kasetsart University for supporting a research assistant in the laboratory and AVL-AST for providing AVL Boost via AVL AST UNIVERSITY PARTNERSHIP PROGRAM.

\section{Contact Information}

Ekathai Wirojsakunchai, PhD, Assoc. Prof. (Corresponding Author)

fengeka@ku.ac.th

\section{References}

(1) K. Wannatong, et al., New Diesel Dual Fuel Concepts: Part Load Improvement, SAE Technical Paper, 2009-01-1797, 2009.

(2) B. B. Sahoo, N. Sahoo, N., and U. K. Saha, Effect of engine parameters and type of gaseous fuel on the performance of dual-fuel gas diesel engines, Renewable and Sustainable Energy Reviews, vol. 13, pp. 1151-1184, 2009.

(3) R. G. Papagiannakis and D. T. Hountalas, Combustion and exhaust emission characteristics of duel fuel compression ignition engine operated with pilot Diesel fuel and natural gas, Energy Conversion and Management, vol. 45, pp. 2971-2987, 2004 
4) A. Harada, et al., The Effects of Mixture Formation on Premixed Lean Diesel Combustion Engine, SAE Technical Paper 980533, 1998.

(5) H. Akagawa, et al., Approaches to Solve Problems of the Premixed Lean Diesel Combustion, SAE Technical Paper, 1999-01-0183, 1999.

(6) F. Wahlin, A. Cronhjort, U. Olofsson, and H. E. Ångström, Effect of Injection Pressure and Engine Speed on Air/Fuel Mixing and Emissions in a Pre-Mixed Compression Ignited (PCI) Engine Using Diesel Fuel, SAE Technical Paper, 200401-2989, 2004

(7) K. Kongsri, W. Wachirapan, and E. Wirojsakunchai, "Design and Development of Synthetic Exhaust Gas Generating System", presented at The $25^{\text {th }}$ Conference of the Mechanical Engineering Network of Thailand, October 19-21, held by Thai Society of Mechanical Engineers, Aonang Villa Resort, Krabi, 2011.

(8) K. Kumsinlar, T. Aroonsrisopon, and K. Wannathong, Effects of Coolant Temperature on Operating Characteristics of a Diesel Dual Fuel Engine", presented at The $25^{\text {th }}$ Conference of the Mechanical Engineering Network of Thailand, October 1921, held by Thai Society of Mechanical Engineers, Aonang Villa Resort, Krabi, 2011.

(9) K. Hemsuk, Effect of Ignition Timing on Performance, Exhaust Gas Temperature, and Emissions of a Diesel Engine Converted for use with Natural Gas Fuel, M.S. Thesis, Kasetsart University, 2009.

(10) B. Choi, G. Son, E. Kim, and K. Lee, Effective Parameters on the Catalytic Reaction of NGV Catalytic Converter, SAE Technical Paper 960239, 1996.

(11) H. J. Stein, Diesel oxidation catalysts for commercial vehicle engines: strategies on their application for controlling particulate emissions, Applied Catalysis B: Environmental, vol. 10, pp. 69-82, 1996.

(12) Y. Nakisa, The role of gas hourly space velocity and feed composition for catalytic oxidative coupling of methane: Experimental study, Journal of King Saud University Engineering Sciences, vol. 25, pp. 1-10, 2013.

(13) S. A. Shahamiri and I. Wierzba, Modeling catalytic oxidation of lean mixtures of methane-air in a packed-bed reactor, Chemical Engineering Journal, vol. 149, no. 1-3, pp. 102-109, 2009.

(14) R. Abbasi, L. Wu, S. E. Wanke, and R. E. Hayes, Kinetics of Methane Combustion over Pt and Pt-Pd Catalysts, Chem. Eng. Res. Des., vol. 90, pp. 1930-1942, 2012.

(15) S. Sumiya, et al., Highly Robust Diesel Oxidation Catalyst for Dual Mode Combustion System, SAE Technical Paper 2009-01-0280, 2009.

(16) R. Kikuchi, et al., Catalytic activity of oxide-supported Pd catalysts on a honeycomb for low-temperature methane oxidation, Applied Catalysis A: General, vol. 239, pp. 169179, 2003.

(17) P. Gélin, L. Urfels, M. Primet, and E. Tena, "Complete oxidation of methane at low temperature over Pt and Pd catalysts for the abatement of lean-burn natural gas fuelled vehicles emissions: influence of water and sulphur containing compounds," Catalysis Today, vol. 83, pp. 45-57, 2003.

(18) G. Lapisardi, et al., "Superior catalytic behaviour of Pt-doped Pd catalysts in the complete oxidation of methane at low temperature", Catalysis Today, vol. 117, pp. 564-568, 2006.

(19) R. Gholami, et al., Deactivation of Pd Catalysts by Water during Low Temperature Methane Oxidation Relevant to Natural Gas Vehicle Converters, Catalysts, vol. 5, pp. 561$594,2015$.

(20) W. Wachirapanb, Parameters that Effect Diesel Oxidation Catalyst Performance on CO and HC Reduction from Diesel
Engines Adapted to Diesel Dual Fuel, M.S. Thesis, Kasetsart University, 2013.

(21) K. Kallinen, et al., Advanced Catalysts for CNG Engines, 2004-28-0028, SAE Technical Paper, Warrendale, PA, 2004.

(22) S. Jirawongnusona, W. Wachirapanb, T. Suthiprasert, and E. Wirojsakunchai, A Parametric Study of Diesel Oxidation Catalyst Performance on CO Reductions in Diesel Dual Fuel Engine Exhaust, Key Engineering Materials, Vol. 656-657, pp. 538-543, 2015.

(23) R. Abbasi, L. Wu, S. E. Wanke, and R. E. Hayes, Kinetics of Methane Combustion over Pt and Pt-Pd Catalysts, Chemical Engineering Research and Design, vol. 90, no. 11, pp. 193042, 2012.

(24) M. Li-Ping, B. Hans-Jörg, N. Ping, and Z. Aimin, Kinetic Study of Three-Way Catalyst of Automotive Exhaust Gas: Modeling and Application, Chemical Engineering Journal, vol. 155, no. 1-2, pp. 241-47.

(25) T. Suthipraset, et al., An Implementation of $\mathrm{CH}_{4}$ Kinetic Model with $\mathrm{H}_{2} \mathrm{O}$ into 1-Dand 3-D Catalytic Converter Simulation Codes, SAE Technical Paper 2017-01-2382, 2017.

(26) T. Shamim, The Effect of Space Velocity on the Dynamic Characteristics of an Automotive Catalytic Converter, SAE Technical Paper 2005-01-2160, 2005.

(27) N. Yaghobi, The Role of Gas Hourly Space Velocity and Feed Composition for Catalytic Oxidative Coupling of Methane: Experimental Study, Journal of King Saud University Engineering Sciences vol. 25, no. 1, pp. 1-10.

(28) D. C. Montgomery, Design and Analysis of Experiments, John Wiley and Sons, Inc., 2009. 